\title{
OCHRONA KULTURY NARODOWEJ W KONCEPCJACH WSPÓtCZESNEJ PRAWICY NARODOWEJ W POLSCE
}

\author{
PROTECTION OF NATIONAL CULTURE \\ IN CONCEPTS OF THE CONTEMPORARY \\ NATIONAL RIGHT WING IN POLAND
}

\begin{abstract}
In the centre of the system of values of the National Right Wing which revived after 1989 there are still nation, family and religion. The nation as community of culture is in opinion of the said parties exposed to dangers. The main risks are in their opinion as follows: cosmopolitism, Communist ideology, individualism, liberalism; secularization.In Poland, such ideas are, in the opinion of the National Right Wing, propagated by the liberal and post-communist circles. In the beginning they demanded that the communist activists are brought to justice. Some columnists refer to antisemitism. They perceive also the fall of the literary output. They assess critically the novels of Czesław Miłosz, Stanisław Barańczak or Olga Tokarczuk. Similar assessments regard the works of Polish historians. As preventive measures the following is mentioned: appropriate educational activity, statutory protection of national heritage, broadening of Catholicism, promotion of national culture.

They attach great importance to the national branding. Its components are history, language, political regime, architecture, literature, art, religion, icons landscape, music. They would probably accept the opinion of Michael Porter: "Many contemporary discussions of international competition stress global homogenization and a diminished role for nations. But, in truth, national differences are at the heart of competitive success."
\end{abstract}

Key words: National Right Wing; national heritage; national branding; community of culture
GRZEGORZ RADOMSKI

Uniwersytet Mikołaja Kopernika, Toruń E-mail: g.radomski@wp.pl This work was supported by the author's own resources. No competing interests have been declared.

This is an Open Access article distributed under the terms of the Creative Commons Attribution 3.0 PL License (creativecommons.org/licenses/by/3.0/pl/), which permits redistribution, commercial and non-commercial, provided that the article is properly cited. () The Author(s) 2015.

Publisher: Institute of Slavic Studies, Polish Academy of Sciences [Wydawca: Instytut Slawistyki PAN] 
W centrum systemu wartości odrodzonego po 1989 roku ruchu narodowego pozostają naród, rodzina i religia. Naród, traktowany jako wspólnota kultury, narażony jest w ocenie wspominanych wyżej środowisk na liczne zagrożenia. Za najgroźniejsze uznają one: kosmopolityzm, ideologię komunistyczną, indywidualizm, liberalizm, sekularyzację. W Polsce wspomniane idee mają być propagowane przez środowiska liberalne i postkomunistyczne. W wypowiedziach publicystów narodowych pojawiają się także akcenty antysemickie. Krytyczna ocena dotyczy też współczesnej polskiej literatury, a zwłaszcza twórczości Czesława Miłosza, Stanisława Barańczaka czy Olgi Tokarczuk. Podobne oceny odnoszone są do prac polskich historyków. Za istotną uznano więc puryfikację kultury narodowej. Wśród środków zaradczych środowiska narodowe proponują: rozwój edukacji historycznej, ochronę dziedzictwa narodowego, rozwój katolicyzmu i promocję kultury narodowej. W tym ostatnim wypadku za niezwykle ważny uznają one branding narodowy. Jego podstawowe składniki to historia, język, architektura, krajobraz, reżim polityczny itp. Polscy narodowcy zapewne zaakceptowaliby opinię sformułowaną przez Michaela Portera. Twierdzi on, iż co prawda nastąpiła globalna homogenizacja, ale podkreślanie odrębności narodowej jest źródłem sukcesu.

Słowa kluczowe: kultura narodowa; prawica narodowa; Polska; odrębność narodowa

W centrum systemu wartości odrodzonego po 1989 roku ruchu narodowego w Polsce pozostaje nadal naród, rodzina i religia'. Nie wnikając w różne sposoby rozumienia narodu i jego definiowania, należy wskazać, iż niejednokrotnie traktowany jest on jako wspólnota kultury (Jaskułowski, 2012; Kłoskowska, 1996, s. 24; Kurczewska, 2000)². Jeden z publicystów Narodowego Odrodzenia Polski pisał:

Naród jest dobrowolnym, opartym na więzi psychicznej i moralnej związkiem ludzi posiadających - wynikające ze wspólnych przodków i historycznej tradycji - poczucie odrębności kulturowej i chęć zachowania jej oraz rozwój („Narodowe Odrodzenie Polski”, 2005, s. 275).

Nie oznacza to jednak akceptacji dla postrzegania kategorii narodu jako pewnego sposobu konstruowania świata społecznego. Akceptując konieczność powołania sieci rekreatorów kultury, a więc instytucji zajmujących się jej dystrybucją, nie podzielano w omawianym środowisku tezy, iż proces dyskursywnego konstruowania narodu wyprzedza jego ukonstytuowanie się. Doceniano jednak aspekt pedagogiczny i performatywny działalności elit politycznych i artystycznych. Jeśli więc nacjonalizm rozumieć jako dyskurs, to zadaniem elit intelektualnych jest prowadzenie ludzi przez świat tak, aby myśleli zgodnie z ideą narodu ${ }^{3}$. Kultura bowiem, jak zauważył jeden z nacjonalistycznych krytyków i twórców literackich, narzuca szlaki naszym myślom i postępkom. „Przynosi uzasadnienie naszym czynom - jest systemem odniesienia. Bez kultury nie byłaby możliwa moralna

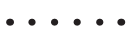

1 Na początku III RP wystąpiły komplikacje dotyczące zaliczenia poszczególnych grup do nurtu narodowego. Najogólniej mówiąc, zaliczyć można do niego różne organizacje i środowiska nawiązujące do tradycji Narodowej Demokracji. Do najistotniejszych ugrupowań można zaliczyć: Stronnictwo Narodowe, Stronnictwo Narodowe "Ojczyzna”, Polską Wspólnotę Narodową - Polskie Stronnictwo Narodowe, Narodowe Odrodzenie Polski, Ruch Narodowy oraz oczywiście Ligę Polskich Rodzin (szerzej patrz: Maj \& Maj, 2007; Tomasiewicz, 2003).

2 W konsekwencji w opinii Ernesta Gellnera dla reprezentantów wyżej wspomnianej ideologii naród jest przede wszystkim wspólnotą kultury. Podobnie twierdził Anthony Smith: „Wszystkie odmiany nacjonalizmu uznają naród za formę publicznej kultury, otwartej w zasadzie dla wszystkich członków wspólnoty lub wszystkich obywateli państwa narodowego".

3 Krzysztof Jaskułowski zauważył, iż „Dyskurs stawiający w centrum kulturę narodową można pojmować jako jeden ze sposobów konstruowania rzeczywistości" (Jaskułowski, 2012, s. 54). 
ocena postępowania, ani żadne wytyczanie dróg dla ludzkiego działania" (Pietrzak, 1937, s. 2). Podobnie więc jak u Jeana Amery'ego, kulturowo ukształtowany proces identyfikacji z własnym narodem stawał się swoistym biotopem składającym się z czynności znaniarozpoznania oraz wierzenia-ufania (patrz: Orłowski, 2006, ss. 309-322).

Kultura staje się więc jednym z głównych składników tożsamości narodowej. W debacie poprzedzającej nowelizacje jednej z ustaw poseł Ligi Polskich Rodzin stwierdzał, iż „naród żyje poprzez kulturę i dla kultury". W takiej optyce istotne jest pojmowanie kultur jako przestrzeni oddzielonych - jak pisał współzałożyciel Narodowej Demokracji Jan Ludwik Popławski - świętą bruzdą od innych (patrz: Karpus \& Stachowiak, 2010). Co jednak istotne, odgraniczona przestrzeń może być postrzegana jako element szerszej całości. Albowiem proklamacja odrębności i wspaniałości grupy własnej jest tu nie aktem zamknięcia się i wyłączenia, lecz próbą jej usytuowania w obrębie szerszej całości, której częścią są inne grupy tego rodzaju (Szacki, 1997, s. 11)4.

Wszakże jeśli uznać, iż kultura narodowa konceptualizowana jest jako przestrzeń, rodzaj figury wykrojonej z większej całości, to istotne jest określenie jej cech swoistych i ich ochrona. Prominentny działacz Młodzieży Wszechpolskiej, a następnie Ligi Polskich Rodzin, Wojciech Wierzejski pisat:

Kluczową rolę w utrwalaniu istnienia narodu odgrywa świadomość narodowa, a umacnianie tejże stanowi zasadniczą (podstawową) naukę ruchu narodowego, dążącego do zachowania i rozwinięcia samej substancji narodowej (Wierzejski, 2001, s. 61).

Puryfikacja prowadzi często do precyzowania kanonu odpornego na infiltrację zewnętrzną. Własna kultura nie może być więc przedmiotem negocjacji. W programie wyborczym Ligi Polskich Rodzin znalazł się następujący passus:

Duchowym dobrem Narodu i moralną racją jego istnienia jest kultura. (...) Naród czerpie z dorobku wspólnego całej cywilizacji, ale dzieła jego wytwórczości są w ostatecznym rozrachunku jego własne, stanowią o jego odrębności i cywilizacji („Liga Polskich Rodzin”, 2005, s. 152).

Dopełniając to stwierdzenie, w deklaracji Ruchu Narodowego z 2012 roku zapisano: "Ruch narodowy za swój podstawowy cel obiera obronę i umacnianie polskiej tożsamości narodowej". W punkcie piątym natomiast, zatytułowanym Suwerenność narodu, stwierdzono:

Naród tylko wtedy jest niepodległy, kiedy myślenie jego elit jest niezależne od zewnętrznych ośrodków i zakorzenione w jego historii. Ruch narodowy będzie rozwijał oryginalną polską myśl polityczną. Przywróci powagę i wielkość polskiej kulturze tak, by ponownie stała się atrakcyjna dla innych narodów także jako gwarant uniwersalnych wartości (Deklaracja ideowa Ruchu Narodowego, 2012).

We fragmencie tym można wyraźnie dostrzec odwołania do myśli jednego z współtwórców idei polskiego nacjonalizmu, Zygmunta Balickiego. Posługiwał się on terminem indukcja, odnosząc go do właściwości myśli politycznej. Polegać ona miała na rodzimym, a nie obcym pochodzeniu ściśle związanym z miejscowymi, a nie obcymi uwarunkowaniami. Łączy się z tym również odrzucenie idei mesjanistycznych i internacjonalistycznych jako niezwiązanych z interesem własnego narodu. Indukcja w myśli politycznej była rozumiana w mniejszym stopniu jako przeciwieństwo internacjonalizmu i kosmopolityzmu,

\section{-....}

4 Nacjonalistyczny publicysta Karol Ludwik Koniński pisał: „Rodzimy się w kulturze, jakbyśmy rodzili się w samolocie unoszącym się ponad otchłanią i wysiąść z kultury nie możemy, nic nam nie pomoże, gdyby pilot nagle motory powstrzymał - tak czy owak, czeka nas upadek samolotu" (Koniński, 1929, s. 58). 
natomiast przede wszystkim jako nakaz jej rodzimości i zakaz holistycznego kopiowania obcych idei (Smolik, 2013, ss. 89-92). W konsekwencji działacze omawianego środowiska zmierzają do budowania marki narodowej, a więc odwołując się do współczesnej terminologii, akceptują zasady brandingu narodowego. Wiąże się to postulatem ochrony polskich symboli narodowych. Uznano to za obowiązek, albowiem "nawet najlepsze prawo nie jest w stanie w pełni czuwać nad właściwym traktowaniem symboli narodowych. Zatem to od reakcji tych wszystkich, którzy rozumieją, jak winny być one traktowane zależy, czy będzie im oddawana cześć" (Radomski, 2006, s. 222). Starają się jednak dobierać atrybuty polskości w ten sposób, aby wykazać odrębność od innych narodów. Ochrona kultury narodowej wynika z powszechnie postrzeganego jej zagrożenia. Jak pisał na początku transformacji jeden z publicystów:

W frenetycznie przekształconym świecie tradycje uważamy za skuteczną tarczę chroniącą osobowość i tożsamość narodu przed promieniowaniem kosmopolitycznych procesów, w których więdną tradycyjne systemy wartości, rozpada się rodzina, rwą się więzy między pokoleniami i niwelują się cechy narodowe, by stworzyć anonimowy świat - sumę jednostek nijakich i sobie podobnych (Przybylski, 1999, s. 49).

Również w tym wypadku można dostrzec nawiązanie do własnej tradycji ideowej. W publicystyce endeckiej rozważano kryzys kultury i jego przyczyny. Wskazywano na obecność mas w kulturze, pewną dysfunkcjonalność występującą w demokracji zachodnioeuropejskiej, standaryzację zachowań i postaw ludzkich, utratę zdolności twórczych W wielu dziedzinach. W konsekwencji: „W zamian za to mamy powieścidełka Tokarczuk i wierszyki Barańczaka”. A radykalny publicysta pisze wprost: "Słowiańskie muzy ciągle milczą, bez nich dusza Polaka-aryjczyka nie obudzi się do pełnej egzystencji" (Larkowski, 1998, s. 5). Współcześni radykałowie dodają do tego zjawisko imigracji. W budzącym niesmak stylu wypowiada się Adam Gmurczyk :

To już nie małe grupki Europejczyków przemieszczają się po kontynencie, ale cała rzesza cywilizacyjnie obcego elementu opanowuje poszczególne kraje, zmieniając chrześcijańską i narodową Europe - poprzez przenoszenie własnych tradycji - w prawdziwy chlew kulturowy (Gmurczyk, 1997, s. 13).

Natomiast za przejaw kosmopolityzmu uznaje się:

- zwrócenie uwagi na wartości ogólnoludzkie i uniwersalne,

- lekceważenie kategorii interesu narodowego,

- akceptację dla tendencji integracyjnych, m.in. dążenie do budowy organizmów ponadnarodowych,

- deprecjację kultury narodowej.

Stwierdzając istnienie jednostek, które uległy kosmopolitycznym złudzeniom, zakładano wszakże możliwość ich powrotu "na obszar lądu narodowego".

Za przejaw upadku narodowcy uznają kult młodości. W ramach reakcji propagują rzymską paremię Seniores priores. luniores ad labores (Wierzejski, 2001, ss. 117-118). Konstatuje się też, iż Kościół zrezygnował z walki o kulturę (Gędłek, 2014, s. 9). Niektóre wypowiedzi o charakterze antyglobalizacyjnym wpisują się zresztą doskonale w lęki i trwogi dzisiejszych społeczeństw. Z jednym istotnym wszakże zastrzeżeniem. Współcześni narodowcy odrzucają zdecydowanie wszelkie neopogańskie czy popkulturowe wizje katastroficzne w rodzaju kalendarza Majów. Myślę, że zaakceptowaliby pogląd Umberto Eco, który pisał: 
Waże się twierdzić, że myśl o końcu czasów jest obecnie bardziej znamienna dla świata laickiego niż chrześcijańskiego. Albo inaczej: świat chrześcijański wprawdzie nad tą sprawą rozmyśla, ale postępuję tak, jak gdyby zasadniejsze było rzutowanie jej w wymiar niepodlegający rachubie kalendarzowej, natomiast świat laicki udaje, że ją ignoruje, w rzeczywistości zaś przeżywa ja głęboko i obsesyjnie (Eco, 2001, s. 9).

Powszechnie postrzegana detradycjonalizacja oraz dominacja popkultury sugerują petryfikację kanonu ukształtowanego w przeszłości. W enuncjacjach narodowców pojawiają się co prawda wezwania do przewartościowań czy reagowania na wyzwania współczesności, ale dominuje pogląd, iż niezbędna jest ochrona tego dorobku, który już został ukształtowany w przeszłości. Uzasadnieniem jest krytyczna ocena współczesnych osiągnięć artystycznych. Stanisław Stanik, krytyk literacki, na łamach „Myśli Polskiej” konstatował:

Nie ma pisarzy ostatnich czasów, którzy jak Żeromski mogliby być określani mianem sumienia narodu. Przeinaczają nasze dzieje, niedowartościowują, ośmieszają. A literatura mająca wspomagać budowanie narodu (w jak najszerszym sensie) jest potrzebna, wręcz nieodzowna; dlatego - co by nie sądzić o Żeromskim - muszą być następcy: chcący iść jego śladem, podpowiadający, jak wybijać rytm na werblu budzącym czujność naszej polskości (Stanik, 2005, ss. 14-15).

Negatywnie oceniane są nowe prądy literackie. W odniesieniu do twórczości Gombrowicza używa się określenia „nowatorstwo upozorowane”. Równie negatywnie oceniana jest kultura europejska:

Dzisiejszy Zachód to gejsza na zewnątrz piękna i błyskotliwa, ale do szpiku zepsuta, jednak mimo to, a może właśnie dlatego, piekielnie atrakcyjna. Przed nią to szczególnie powinna bronić się Polska, a swoją postawą po raz kolejny uchronić ją przed zagładą (Strutyński, 2006, s. 388).

Wyraźna jest też niezgoda na „sprowincjalizowanie" Zachodu i przyjęcie postawy postkolonialnej. Uznanie równowartości kultur prowadzi bowiem ich zdaniem do relatywizmu. Eurosceptyzm Ligi Polskich Rodzin wynikał przede wszystkim z postrzegania rzekomego zagrożenia dla podstaw „narodowego stylu życia”:

Unia Europejska dąży do wygaszania narodowych kultur i zbudowania na ich gruzach quasi -kultury hedonistyczno-utylitarnej, będącej charakterystycznym rysem współczesnej europejskiej tożsamości (Morska, 2010, s. 265).

Wyjątkowo wśród narodowych rewolucjonistów pojawia się akceptacja dla artystycznego dorobku awangardy czy środowisk kontrkultury. Jak obrazowo pisał jeden z publicystów internetowego periodyku:

Wierzy w sens tego, co się dzieje. W ruinach i gruzowiskach kryje się metaforyczne piękno, że trawy i mchy porastające zgliszcza to początek nowego życia. Nawet grzyby, bakterie i pierwotniaki to mali pracowici agenci Pana Boga. Rewolucyjny postkonserwatysta krąży po świecie ruin i czuje się w nim tak, jakby umieszczono go na obrazie Maxa Ernsta Europa po deszczu. Bierze z tego świata odpadków to, co użyteczne (Radomski, 2012, s. 215).

Z kolei hasło Polonia semper fidelis określa jej katolicki wymiar. Obowiązuje nadal wyznaniowy identyfikator przynależności narodowej. Hasło Polak-katolik znalazło praktyczny wymiar w statucie jednej z partii politycznych, której członkami mogli zostać tylko wyznawcy wspomnianej wyżej religii. Katolicyzm stanowi fundament jedności narodowej oraz inspirację dla kształtowania kultury narodowej. W deklaracji ideowej Sekcji Młodych Stronnictwa Narodowego w 2001 roku zapisano: 
Wiara rzymskokatolicka stanowiąca podstawowy filar naszej cywilizacji jest wyznacznikiem moralnym naszej pracy. (...) W Kościele katolickim uznajemy głównego wychowawcę etycznego naszego narodu, nadając mu charakter nadrzędny w stosunku do innych równoprawnych wyznań chrześcijańskich. Doceniamy też niezaprzeczalną rolę Kościoła Katolickiego w formowaniu się tożsamości i jedności narodowej naszej Ojczyzny (Deklaracja ideowa Sekcji Młodych Stronnictwa Narodowego, 2001).

Nieprzypadkowo więc w kanonie lektur propagowanych w okresie, gdy funkcję ministra edukacji narodowej pełnił polityk Ligi Polskich Rodzin znalazło się miejsce dla dzieł katolickiego pisarza Jana Dobraczyńskiego, Hanny Malewskiej czy rozmyślań papieża. Eksponowane są w publicystyce te wątki z homilii Jana Pawła II, które charakteryzują naród polski jako katolicki:

Powszechnie się przyznaje, że ów, wynikający z katolickiej jedności Kościoła, udział Narodu Polskiego $w$ duchowym dziedzictwie tego Kościoła stał się czynnikiem łączącym oraz zabezpieczającym tożsamość (...) Narodu w okresach szczególnie trudnych (Radomski, 2009, s. 154).

Prezentowane są fragmenty biografii, w których papież informuje, że codziennie odmawia litanię do narodu polskiego. Nie znajdują natomiast uznania te działania artystyczne, które kwestionują związek narodu polskiego z katolicyzmem. Świadczą o tym protesty wobec obrazów Doroty Nieznalskiej czy Artura Żmijewskiego. Niektórzy publicyści wręcz twierdzą, że poza chrześcijaństwem nie ma prawdziwej kultury (Hall, 1997, s. 43)5. Zdecydowanie negatywnie odnoszono się do aspektów erotycznych i sensualistycznych w literaturze. Tradycyjnie wyznaczano kobietom do wypełnienia następujące funkcje: biologiczną reprodukcję członków narodu, utrwalanie granic grup narodowych, udział w ideologicznej reprodukcji wspólnoty, bezpośredni udział w walkach nacjonalistycznych (Floya \& Yuval-Davis, 1996, ss. 68-90).

Pamiętać też należy, iż endecy akceptowali w pełni tezę Stanisława Piaseckiego, który pisał: „między twórczością a życiem twórcy zachodzi ścisły związek, że nie tylko tworzyć trzeba pięknie, że osobiste życie artysty jest równie ważne jak jego sztuka, bo jest tej sztuki źródłem" (Urbanowski, 2006, s. 68). Co więc istotne, nawet jeśli twórczość oceniano jako obcą i niebezpieczną, to wcale nie oznaczało deprecjacji dokonań artystycznych. A jeden ze współczesnych publicystów, odnosząc się do pochówku Czesława Miłosza na Skałce, zapisat: "Tylko czy kunszt zawodowy ma być furtką do krypt wielkich Polaków” (Engelgard, 2004, s. 1). W tym wypadku znowu więc doceniano wartości warsztatu, odrzucając idee określane mianem „pseudointelektualnego betkotu” (Stanik, 2004, s. 15).

Ważne miejsce w formowaniu świadomości narodowej przypisywane jest historii. Jak pisał publicysta „Wszechpolaka”: „Przykłady na marnotrawstwo dorobku naszych przodków można by mnożyć niemal w nieskończoność" (Szołucha, 2003, s. 51). Krytycznie oceniane są wszystkie wypowiedzi ukazujące Polaków w roli prześladowców - przykładem najbardziej jaskrawym była kampania prowadzona w sprawie Jedwabnego. Wszelkie zresztą wypowiedzi dotyczące polskiego antysemityzmu są komentowane krytycznie (patrz: Maj, 2006, ss. 389-406). Z dezaprobatą przyjęto także próby nowego spojrzenia na dzieje zakonu krzyżackiego czy starć polsko-ukraińskich. Eksponowana jest w tym wypadku teza, iż aby pozbawić młodego człowieka zbędnego z punktu widzenia eurokratów balastu tożsamości narodowej, eksponuje się „czarne karty z historii Polski”. Przedmio-

\section{......}

5 Zasadnie więc pisał Aleksander Hall: „mają też skłonność do interpretowania formuły Dmowskiego (z pracy Kościót, Naród, państwo), stwierdzającej nierozerwalny związek polskości z katolicyzmem, w taki sposób, że w istocie czynią z katolicyzmu ideologię spychającą na margines niekatolików". 
tem sporu jest ocena „żołnierzy wyklętych”. Część działaczy wywodzących się z Paxu krytycznie ocenia ich program ideowy. Dla innych jest to natomiast przejaw odrodzenia zainteresowania historią i ułatwia odpowiednią formację ideową.

Zamiast puryfikacji pojawia się jednak dążenie do realizacji określonych założeń ideowych i wręcz instrumentalizacja. Dostrzec to można chociażby w stosunku do tak zwanych ziem zachodnich, wobec których stosowana jest typowa zasada kolonizacji pejzażu kulturowego. Generuje się ciągle pamięć własną i propaguje odcięcie od obcej, w tym wypadku niemieckiej, kultury. Podkreślaniu polskiego charakteru tych terenów służą inicjatywy edukacyjne czy propagowanie odpowiedniego zestawu lektur. Z kolei na kresach wschodnich kultura może doprowadzić do odrodzenia świadomości polskiego charakteru tych ziem. Nieświadomie więc chyba są rzecznikami poglądu, iż pamięć kulturowa rejestruje nie faktyczną, lecz tylko wspominaną, pamiętaną historię. Istniejące zagrożenia skłaniają do zaprojektowania środków zaradczych. Ich katalog jest jednak dość ubogi i rzadko prezentowany. O wiele częściej analizowane są zagrożenia. Neoendecy dostrzegają przede wszystkim znaczącą rolę elit także na polu kultury. W tym wypadku dostrzega się dominację elit o proweniencji liberalnej: „ta część narodu, która jest aktywna na płaszczyźnie kultury i sztuki niezależnie od kierunków zainteresowań czy gustów, stanowi tę część społeczeństwa, która znaczącym stopniu oddziałuje na całość. Dziś ani ruch narodowy, ani nawet szeroko rozumiane środowiska konserwatywne czy prawicowe nie mają w tej sferze odpowiedniego wpływu" (patrz: Jajecznik, 2013, ss. 368-370). Środkom masowego przekazu zarzuca się manipulację oraz świadome demoralizowanie młodego pokolenia. Jako przykład wskazuje się modę na noszenie koszulek i innych gadżetów z symbolami totalitaryzmu i komunizmu. Przodować mają w tym celebryci sztucznie wykreowani przez media. W konsekwencji obecne są co najmniej dwie strategie działania. Pierwsza ma wymiar bardziej defensywny i została zwerbalizowana przez Rafała Larkowskiego z NOP-u:

Nie posiadając sitą rzeczy masowego aparatu kulturowego oddziaływania na naród, musimy z konieczności wyszukiwać pozytywne przykłady działań z kręgu bardziej spolszczonych przedstawicieli demoliberalizmu (Larkowski, 2000 , s. 9).

Z pozytywnym oddźwiękiem współczesnych nacjonalistów spotkał się film Śmierć jak kromka chleba krytykowanego Kazimierza Kutza czy Pan Tadeusz Andrzeja Wajdy, mimo krytyki wypowiedzi wspomnianego reżysera. Podejmowane są próby propagowania twórczości cenionych w omawianym środowisku artystów. Promowany jest dorobek literacki Jana Huberta Rostworowskiego oraz Chestertona. Z aprobatą spotkały się dzieła Lucyny Ogińskiej oraz twórczość filmowa Bohdana Poręby. Ta druga, związana z sukcesami LPR i aprobatą założeń francuskiej nowej prawicy, łączyła się z „odzyskaniem pojęć języka publicznego”. Jak konstatowano bowiem, „władza tkwi w zdolności do skutecznej komunikacji i modyfikowania języka" (Bonisławski, 2008, s. 19). Wyrażona nadzieja na osiągnięcie wpływu na sposób myślenia obywateli wiąże się z akceptacją zastosowania różnych środków oddziaływania socjotechnicznego. W konsekwencji wyrażają nadzieję na odzyskanie wpływu wśród inteligencji, co w istotny sposób ich zdaniem może wpłynąć na możliwości ochrony kultury narodowej. Daniel Pawłowiec odwołujący się do koncepcji "łagodnego panowania" wskazuje, iż twórcy obozu wszechpolskiego potrafili zdobyć wpływ na kształtowanie mentalności rodaków poprzez związanych ze swoim obozem artystów i naukowców. Idea aliansu środowisk kreujących nowy dyskurs przyświecała grupom wydającym dwa reprezentatywne czasopisma, „Myśl Polską” i „Politykę Narodową". Wymienione tytuły są jednymi z wielu, narodowcy bowiem tradycyjnie dużą wage przywiązują do komunikacji politycznej, redagując szereg czasopism, wśród których wy- 
mieńmy jeszcze „Wszechpolaka” i „Szczerbiec”. Można się też zgodzić, iż do syndykatu metapolitycznego zaliczyć powinno się także kwartalnik „Myśl.pl.” Antidotum na zagrożenia ma stanowić powrót do dawnych wzorców pedagogicznych, między innymi poprzez przywrócenie etosu nauczyciela i szkoły. Z inspiracji środowiska odbywają się coroczne konferencje dotyczące roli nauczyciela i koncepcji wychowawczych. Opracowywane są kompleksowe projekty reformy oświaty, a w bieżącej działalności organizowane są konkursy historyczno-literackie dotyczące wybitnych postaci, jak Piotr Skarga, kardynał August Hlond czy Józef Haller (Giertych, 1994, ss. 41-42; Jaworska, 2003, ss. 118-128; Skurzak, 2006, ss. 22-23). W propagowanym modelu wychowania zwraca się uwage na karność, wytrwałość, aktywność społeczną, łączoną z budzącym niepokój żądaniem nabycia umiejętności "identyfikacji wrogów ojczyzny”. Z inicjatywy młodych narodowców odbywają się też konferencje i spotkania z nestorami ruchu narodowego. Radni o orientacji narodowej zgłaszają wnioski dotyczące nazewnictwa ulic, placów czy patronów instytucji. Przykładem może być kampania na rzecz nazwania ronda w Szczecinie imieniem Romana Dmowskiego. Monitorowany jest skład personalny instytucji promujących kulture i instytucje oświatowe. Z głośnym sprzeciwem spotkała się decyzja o powołaniu profesora Tadeusza Cegielskiego w skład rady programowej zespołu pałacowo-parkowego w Dobrzycy. Zarzucono wymienionemu naukowcowi przynależność do masonerii.

Dostrzegając brak akceptacji dla mowy nienawiści, narodowcy często posługują się językiem ezopowym, odżegnując się oficjalnie od antysemityzmu. Zarzuca się więc nieakceptowanym twórcom działania antypolskie lub obcość cywilizacyjną.

Wielu zwłaszcza młodych działaczy propaguje własne idee w bardziej opiniotwórczych środowiskach, Instytucie Edukacji Narodowej, Stowarzyszeniu Kultury Chrześcijańskiej im. Piotra Skargi, Fundacji Nasza Przyszłość, „Serviri Veritati” czy środowisku Radia Maryja. Działaczy narodowych odnaleźć można w reaktywowanym towarzystwie gimnastycznym Sokół oraz w wielu grupach rekonstrukcji historycznych. Jest to zgodne z opinią jednego z młodszych działaczy, Krzysztofa Bosaka, który stwierdzit:

W pierwszej kolejności trzeba odrzucić przedwojenny paradygmat jedności formacji intelektualnej i politycznej. Wtłaczanie ludzi, których zadaniem jest kreowanie myśli i udział w debacie publicznej, w ramy partyjnej lojalności w dzisiejszych realiach może się skończyć tylko katastrofą (Bosak, 2008, s. 21).

Spektakularny rozgłos uzyskują współorganizowane przez narodowców Marsze Niepodległości. Udaje się przeprowadzić polaryzację na zasadzie polskie - antypolskie. Aby zapobiec "narodowemu minimalizmowi”, Stronnictwo Narodowe Ojczyzna propagowało hasło: „Bądź dumny z tego, że jesteś Polakiem”. Z kolei Młodzież Wszechpolska zamiast walentynek propaguje akcję Kocham Polskę. Organizowane były i są marsze w obronie „normalnej rodziny”, określane mianem Parady Normalności (np. w 2005 roku). W okresie odgrywania istotnej roli politycznej przez LPR starano się wywrzeć wpływ na kształt oświaty narodowej oraz kultury poprzez zajmowanie eksponowanych stanowisk. Członek ugrupowania pełnił funkcję ministra edukacji narodowej, a inni wchodzili w skład władz naczelnych rad programowych telewizji państwowej i radia. Również w opracowanych projektach zmiany konstytucji podkreślano wagę wychowania patriotycznego.

Określenie kanonu kultury narodowej ułatwia publicystom narodowym identyfikację wrogów, umacnia też moralny protest przeciwko rzekomym zagrożeniom z ich strony. Postulowana jest radykalna rewizja pojęć o własnej przeszłości, odrzucenie zarzutów dotyczących win Polaków wobec innych narodów czy uprzedzeń. Poczucie dumy z przynależności do własnego narodu wykreowane na podstawie właściwie dobranych lektur może 
ułatwić realizację budowy suwerennego państwa narodowego. Służy więc instrumentalizacji poprzez tworzenie jednolitego obrazu kultury polskiej, z kręgu której wyłączeni zostaliby twórcy nieskłonni do zaakceptowania zasad tradycjonalizmu katolickiego i ekskluzywizmu narodowego. Kreując się na depozytariuszy narodu, nacjonaliści wyraźnie ograniczają kanon kultury narodowej do twórczości etnicznych Polaków, negując świadomie dużą część dorobku polskiego powstałego w wyniku oddziaływania zewnętrznych wpływów, które akomodowano. Nie służy to ochronie kultury, ale stawia przed Polakami wybór tylko antynomiczny. Preferowane jest przymusowe wpajanie akceptowanych przez nacjonalistów wartości i związana z tym wybiórczo akceptacja cenzury. Niewątpliwie też przywołanie dawnych wzorów osobowych i dzieł sztuki usprawiedliwia się poprzez rzekomo nikły rozwój kultury współczesnej. Partie tworzone przez obóz narodowy wpisują się więc wyraźnie w podział socjopolityczny, który zdaniem Klausa von Beyme odnosi się do osi nacjonalizm - westernizacja, a w ocenie Andrzeja Antoszewskiego tradycjonalizm - westernizacja. Można też postrzegać ten podział w kategorii sporu cywilizacyjnego. Broniąc polskiego i chrześcijańskiego sposobu myślenia, mają narodowcy szanse na akceptację w kręgu środowisk konserwatywnych i tym samym na realizację swoich założeń. Jednocześnie odrzucają oskarżenie o zubożenie polskiej kultury narodowej poprzez odwołanie się do kategorii reasekuracji interesu narodowego. Jeśli więc własna kultura narodowa ma pozostawać w kontakcie z innymi kulturami, to tylko akceptującymi cywilizację łacińską i nacjonalizm. Nie oznacza to jednak pełnej akceptacji dla traktowania kulturowego kontaktu jako walki i w konsekwencji obecnego w ruchach totalitarnych dążenia do całościowej anihilacji kultury obcej (patrz: Bäcker, 2004, s. 150).

\section{BIBLIOGRAFIA}

Bäcker, R. (2004). Instrumentarium ideologiczne kontrakulturacyjnych nurtów antyglobalizacyjnych. W R. Bäcker \& J. Sobczak (Red.), Europejska myśl polityczna wobec globalizacji. Łódź: Ibidem.

Bonisławski, K. (2008). Nadejdzie ten dzień. Pytania o tradycje, formy i treść ruchu. Polityka Narodowa, 1.

Bosak, K. (2008). Bankructwo mitów i rekonstrukcja ruchu. Polityka Narodowa, 2-3.

Deklaracja ideowa Sekcji Młodych Stronnictwa Narodowego. (2001). My, nowe pokolenie!, 1.

Deklaracja ideowa Ruchu Narodowego. (2012). (Druk w zbiorach autora).

Eco, U. (2001). Święte wojny i pasja rozumu. Gazeta Wyborcza, 13-14.

Engelgard, J. (2004). Miłosz na Skałce. Nowa Myśl Polska, 36.

Floya, A., \& Yuval-Davis, N. (1996). Racialized boundaries: Race, nation, gender, colour and class and the anti-racist struggle. London: Routledge.

Gędłek, K. (2014). Czy rośnie nam nowe pokolenie Kolumbów? Myśl.pl, 31. Pobrano 28 maja 2015, z http://mysl24.pl/spoleczenstwo/2528-czy-rosnie-nam-nowe-pokolenie -kolumbow.html

Giertych, R. (1994). Kontrrewolucja młodych. Warszawa: Ad Astra.

Gmurczyk, A. (1997). Wywiad z Adamem Gmurczykiem - prezesem Narodowego Odrodzenia Polski. Armagedon, 1.

Hall, A. (1997). Polskie patriotyzmy. Gdańsk: Info-Trade. 
Jajecznik, K. (2013). Próba integracji młodego pokolenia nacjonalistów wokół pisma „Polityka Narodowa" w latach 2008-2012. W E. Maj \& A. Dawidowicz (Red.), Prasa Narodowej Demokracji (T. 4, Prasa lokalna, regionalna, środowiskowa). Lublin: Wydawnictwo UMCS.

Jaskułowski, K. (2009). Nacjonalizm bez narodów. Nacjonalizm w koncepcjach anglosaskich nauk społecznych. Wrocław: Wydawnictwo Uniwersytetu Wrocławskiego.

Jaskułowski, K. (2012). Wspólnota symboliczna. W strone antropologii nacjonalizmu. Gdańsk: WN Katedra.

Jaworska, M. (2003). Złodzieje pamięci. Cywilizacja, 7.

Karpus, Z., \& Stachowiak, B. (Red.). (2010). Granice i świat wspótczesny. Toruń: Wydawnictwo UMK.

Kłoskowska, A. (1996). Kultury narodowe u korzeni. Warszawa: Wydawnictwo Naukowe PWN.

Koniński, K. L. (1929). Zaufanie do rzeczywistości. Myśl Narodowa, 22.

Kurczewska, J. (2000). Kultura narodowa i polityka. Warszawa: Oficyna Naukowa.

Larkowski, R. (1998). Trzeci front. Szczerbiec, 3-4.

Liga Polskich Rodzin. (2005). W I. Składkowska \& M. Dołbakowska (Red.), Eurowybory 2004. Kandydaci i programy. Warszawa: ISP PAN.

Maj, C., \& Maj, E. (2007). Narodowe ugrupowania polityczne w Polsce 1989-2001. Lublin: Wydawnictwo UMCS.

Maj, E. (2006). Wrogowie narodu i państwa polskiego w koncepcjach Ligi Polskich Rodzin. W S. Stępień. (Red.), Ideologie, doktryny i ruchy narodowe. Wybrane problemy. Lublin: Wydawnictwo UMCS.

Morska, A. (2010). Prawicowy populizm a eurosceptycyzm na przykładzie listy Pina Fortuyna w Holandii i Ligi Polskich Rodzin w Polsce. Wrocław: Wydawnictwo UWr.

Narodowe Odrodzenie Polski. (2005). W I. Składkowska \& M. Dołbakowska (Red.), Eurowybory 2004. Kandydaci i programy. Warszawa: ISP PAN.

Orłowski, H. (2006). Literatura, tożsamość narodowa i pamięć kulturowa na przełomie XX i XXI wieku. W I. Surynt \& M. Zybura (Red.), Opowiedziany naród. Literatura polska i niemiecka wobec nacjonalizmów XIX wieku. Wrocław: Wydawnictwo UWr.

Pietrzak, W. (1937). O nowoczesną kulturę narodową. Młoda Polska, 2.

Przybylski, H. (Red.). (1992). Doktryny polityczne w Polsce. Materiały źródłowe. Katowice: Akademia Ekonomiczna im. Karola Adamieckiego.

Radomski, G. (2006). Globalizacja i jej implikacje dla kultury narodowej w interpretacjach polskiej prawicy narodowej. W E. Ponczek \& A. Sepkowski (Red.), Cywilizacyjna tożsamość europejska a polski patriotyzm. Włocławek: Wydawnictwo PWSZ.

Radomski, G. (2008). Puryfikacja czy instrumentalizacja? Narodowe Odrodzenie Polski wobec kanonu kultury narodowej. W M. Jeziński (Red.), Współczesne nacjonalizmy. Toruń: Wydawnictwo Adam Marszałek.

Radomski, G. (2009). Recepcja myśli Jana Pawła II w koncepcjach współczesnego ruchu narodowego w Polsce. W K. Kalinowska, B. Brodzińska, \& M. Zamojska (Red.), Jan Pawet II i Europa. Toruń: Wydawnictwo UMK.

Radomski, G. (2012). Substancjalistyczne i akcydentalne elementy krytyki demokracji w koncepcjach współczesnego ekstremizmu narodowego w Polsce. W M. Strzelecki (Red.), Między aprobatą a odrzuceniem. Demokracja polska w refleksji i praktyce politycznej XX i XXI wieku. Olsztyn: Wydawnictwo WSTiE TWP.

Skurzak, L. (2006). Co zrobić z polską szkołą. Myśl Polska, 22-23. 
Smolik, B. (2013). Zagadnienie indukcji myśli w polskim nacjonalizmie. Wrocławskie Studia Politologiczne, 14.

Stanik, S. (2004). Nowatorstwo upozowane (2). Nowa Myśl Polska, 32-33.

Stanik, S. (2005). Literatura i polityka. Co z sumieniem narodu? Myśl Polska, 18-19.

Strutyński, M. (2006). Religia i naród. Inspiracje katolickie w myśli ruchu narodowego w Polsce współczesnej 1989- 2001. Kraków: Nomos.

Szacki, J. (1997). O narodzie i nacjonalizmie. Znak, 3.

Szołucha, M. (2003). Z historią na słońce. Rzecz o utylitaryzmie dziejów. Wszechpolak, 1-2.

Tomasiewicz, J. (2003). Ugrupowania neoendeckie w III Rzeczypospolitej. Toruń: Wydawnictwo Adam Marszałek

Urbanowski, M. (2006). Dziedzictwo. Rozmowa (z samym sobą) o Stanisławie Piaseckim. Christianitas, 27-28.

Wierzejski, W. (2001). Naród, młodzież, idea. Zbiór narodowej publicystyki z lat 1997-2000. Krzeszowice: Ostoja. 